\title{
A New Test Required Instead of Tuberculin Skin Test in Liver Transplant Recipients
}

\author{
Mehmet Celikbilek $^{1, *}$, Serkan Dogan ${ }^{2}$ and Haldun Selcuk ${ }^{3}$
}

${ }^{1}$ Department of Gastroenterology and Hepatology, Bozok University School of Medicine, Yozgat, Turkey

${ }^{2}$ Department of Gastroenterology and Hepatology, Erciyes University School of Medicine, Kayseri, Turkey

${ }^{3}$ Department of Gastroenterology and Hepatology, Baskent University School of Medicine, Ankara, Turkey

\section{Dear Editor}

In Liver Transplant (LT) recipients' effective diagnosis and treatment of Latent Tuberculosis (TB) infection is essential because immunosuppression can lead to severe and life-threatening TB reactivation. In addition, the management of latent $\mathrm{TB}$ infection in LT recipients is intricate by the potential of isoniazid induced hepatotoxicity, which can be difficult to discriminate from rejection and other causes of allograft dysfunction as well as possible drug interactions [1]. We want to add some points which may take into consideration about $\mathrm{LT}$ recipients.

The performance of Tuberculin Skin Test (TST) for detection of latent TB infection has been considered to be suboptimal because of false negative results in patients with underlying organ dysfunction, malnutrition, immune suppression, or concurrent viral illness and false-positive results from infection with environmental mycobacteria and Bacille Calmette-Guerin (BCG) vaccination [2]. TST has many limitations including inter-individual variability of placement and reading of TST and the requirement of the patient to return 48-72 $\mathrm{h}$ after placement for test reading [3]. In our experience, LT recipients with viral etiology showed higher PPD results than non-viral etiology and recipients did not develop active TB during follow-up. We concluded that TST is not a reliable method to detect latent TB in cirrhosis patients caused by HBV and HCV [4]. Jafri et al. also found a significantly higher rate of HCV infection in the TST positive subgroup of adult LT candidates and they attributed this higher rate to alcohol abuse [1]. Interferon $-\gamma$ Release Assays (IGRAs) have potentially improved specificity by distinguishing positive TST results due to a previous BCG vaccination or an infection with atypical mycobacteria $[1,5]$. Labue PA et al. mentioned that IGRAs are new diagnostic tools that provide certain advantages over TST [3]. They implicated that each institution should choose suitable test for their target populations. We think that the use of IGRAs in LT recipients might reduce the number of people considered for isoniazid chemoprophylaxis and agree that a blood test might replace the TST in LT recipients.

\section{Acknowledgment}

All authors have no conflict of interest and financial support.

\section{References}

1. Jafri SM, Singal AG, Kaul D, Fontana RJ (2011) Detection and management of latent tuberculosis in liver transplant patients. Liver Transpl 17: 306-314.

2. Kim SY, Jung GS, Kim SK, Chang J, Kim MS, et al. (2012) Comparison of the tuberculin skin test and interferon-y release assay for the diagnosis of laten tuberculosis infection before kidney transplantation. Infection 17.

3. LoBue PA, Castro KG (2012) Is it time to replace the tuberculin skin test with blood test? JAMA 308: 241-242.

4. Celikbilek M, Selcuk H, Yilmaz U (2012) The effect of hepatotropic virus (HBV-HCV) infections on tuberculin skin test in patients with cirrhosis. Turk $J$ Gastroenterol 23: 234-238.

5. Menzies D, Pai M, Comstock G (2007) Meta-analysis: new tests for the diagnosis of latent tuberculosis infection: areas of uncertainty and recommendations for research. Ann Intern Med 146: 340-354
*Corresponding author: Mehmet Çelikbilek, Bozok Üniversitesi Tıp Fakültesi Hastanesi Gastroenteroloji ve Hepatoloji Bilim Dal, Yozgat, Turkey, Tel: +905056615375; Fax: +903542177150; E-mail: drcelikbilek@yahoo.com

Received August 23, 2012; Accepted August 25, 2012; Published August 30 2012

Citation: Celikbilek M, Dogan S, Selcuk H (2012) A New Test Required Instead of Tuberculin Skin Test in Liver Transplant Recipients. J Liver 1:110. doi:10.4172/21670889.1000110

Copyright: () 2012 Celikbilek M, et al. This is an open-access article distributed under the terms of the Creative Commons Attribution License, which permits unrestricted use, distribution, and reproduction in any medium, provided the original author and source are credited. 